\title{
IDENTIFIKASI MIKROBA YANG KOEKSIS DENGAN ASCIDIA Lissoclinum patella MENGGUNAKAN SEKUENS GEN 16S rRNA
}

\author{
(Identification of the co-exist microbial with ascidian Lissoclinum patella by \\ using 165 rRNA gene sequences)
}

\author{
Patricia Untu $^{1^{\star}}$, Inneke F. M. Rumengan ${ }^{1}$, Elvy L. Ginting ${ }^{1}$
}

\author{
1. Program Studi Ilmu Kelautan, Fakultas Perikanan dan IImu Kelautan, Universitas Sam \\ Ratulangi, Manado \\ *e-mail :patricia.untu.100513013@gmail.com
}

This study was conducted to determine the types of co-existed microbes in ascidians Lissoclinum patella with using 16S rRNA gene sequences. The samples that used in this study were taken from tissues of $L$. patella in Malalayang sea water, Manado, North Sulawesi. The samples were inoculated in Hirata medium for \pm 1 week. The DNA were isolated from microbial samples, amplification by using the PCR (Polymerase Chain Reaction), electrophoresis agarose gel and data analyze using BLAST (Basic Local Alignment Search Tool) in NCBI (National Center for Biotechnology Information). The results show, that there are 15 species of microbes in the Gene Bank that have a high degree of similarity with the 16S rRNA gene sequences of microbial sample, namely cyanobacterium enrichment culture CAWBG121 and CAWBG120 clones, uncultured Symploca sp. DRTO clone-55, Leptolyngbya sp. PCC7376 complete genome, Leptolyngbya sp. PCC7376, uncultured bacterium clone PINFEBB02, uncultured bacterium clone 5M47, Synechococcus elongatus CCMP1630, uncultured bacterium clone H09 reef, Synechococcus sp. PCC7002 complete genome, Synechococcus sp. 16S rRNA gene strain PCC7002, Synechococcus sp. DNA for 16 ribosomal RNA, Synechoccous sp. L21-BG-1, Oscillatoria rosea IAM M-220 and Synechococcus sp. PCC 8807 . The level similarity of microbes in the NCBI and the microbial samples ranged between $98-99 \%$.

Keywords: Identification, Co-exist, Ascidian, 16S rRNA gene, Lissoclinum patella

Penelitian ini dilakukan dengan tujuan untuk menentukan jenis mikroba koeksis dengan ascidia Lissoclinum patella menggunakan sekuens gen 16S rRNA. Sampel yang digunakan dalam penelitian ini diambil dari jaringan tissue pada ascidia $L$. patella yang diambil dari perairan Malalayang, Sulawesi Utara. Sampel mikroba diinokulasi dalam media Hirata dan dikultur selama \pm 1 minggu. Sampel mikroba tersebut diisolasi DNA, amplifikasi melalui PCR (Polymerase Chain Reaction), elektroforesis gel agarose dan dianalisis data DNAnya menggunakan BLAST pada NCBI (National Center for Biotechnology Information). Identifikasi yang dilakukan menggunakan BLAST diperoleh hasil 15 mikroba yang memiliki tingkat kemiripan yang tinggi dengan sekuens gen 16S rRNA sampel mikroba yaitu cyanobacterium enrichment culture CAWBG121 dan CAWBG120 clone, uncultured Symploca sp. clone DRTO55, Leptolyngbya sp. PCC7376 complete genome, Leptolyngbya sp. PCC7376, uncultured bacterium clone PINFEBB02, uncultured bacterium clone 5M47, Synechococcus elongatus CCMP1630, uncultured bacterium clone reef H09, Synechococcus sp. PCC7002 complete genome, Synechococcus sp. 16S rRNA gene strain PCC7002, Synechococcus sp. DNA untuk 16 ribosomal RNA, Synechoccous sp. L21-BG-1, Oscillatoria rosea IAM M-220 dan Synechococcus sp. PCC 8807. Tingkat kemiripan mikroba dalam NCBI dengan sampel $\mathrm{H} 1$ berkisar antara 98-99\%.

Kata kunci: Identifikasi, Koeksis, Ascidia, 16S rRNA, Lissoclinum patella

\section{PENDAHULUAN}

Organisme yang dijumpai di dalam lautan memiliki bentuk yang sangat bervariasi. Selain bentuk yang bervariasi, didapati juga adanya interaksi atau hubungan yang terjadi diantara organisme dengan spesies yang berbeda di dalam lautan. Hubungan antar organisme tersebut nampaknya tidak saling merugikan satu 
dengan yang lain, bahkan berguna untuk satu atau keduanya (Nybakken, 1992). Contoh hubungan yang terjalin antar organisme di dalam lingkungan laut adalah ascidia dan mikroba. Hubungan tersebut memberikan keuntungan bagi keduanya (Hirose \& Maruyama, 2004; Donia et al., 2011)

Ascidia adalah golongan tunikata laut yang termasuk dalam organisme invertebrata laut (Schimdt et al., 2005). Lissoclinum patella adalah salah satu spesies ascidia yang mempunyai mikroba di dalam tubuhnya. Penelitian Lewin and Cheng (1989) memberikan informasi awal terhadap keberadaan mikroba di dalam ascidia L. patella yakni prokariot fotosintetik yang dinamakan Prochloron. Keadaan lingkungan dalam tubuh ascidia yang unik (Behrendt et al., 2012) memungkinkan tidak hanya satu mikroba saja yang dapat hidup dan tinggal di dalamnya.

Ascidia L. patella sebagai tempat tinggal dan berlindung (Hirose \& Maruyama, 2004) memberikan kontribusi bagi mikroba untuk dapat hidup dan memproduksi senyawasenyawa bermanfaat khususnya untuk keberlangsungan hidup dari ascidia $L$. patella sendiri. Penelitian Donia et al (2006) menunjukkan bahwa mikroba yang diisolasi dari dalam ascidia $L$. patella dapat menghasilkan suatu senyawa yang dinamakan patellamide. Menurut Schimdt et al. (2005), patellamide adalah produk yang dapat digunakan dalam bidang kesehatan.

Fakta bahwa mikroba yang hidup dalam ascidia $L$. patella dapat bermanfaat bagi kehidupan, membuat penelitian untuk mengeksplorasinya perlu untuk dilakukan. Namun, hingga saat ini masih sedikit penelitian yang dilakukan untuk mengeksplorasi keberadaan mikroba dari ascidia $L$. patella khususnya yang berada di perairan Sulawesi Utara melalui penelitian skala DNA atau skala molekuler. Perkembangan teknologi dalam bidang molekuler seperti teknologi PCR dan DNA Barcoding, memungkinkan untuk dilakukan penelitian hingga pada skala DNA khususnya untuk mengidentifikasi mikroba pada ascidia $L$. patella di perairan Malalayang, Sulawesi Utara. Keuntungan yang diperoleh lewat penelitian skala DNA atau skala molekuler ini adalah kecepatan dan hasil yang didapat lebih spesifik, serta dapat mendeteksi sampai pada tingkat molekul DNA (Biotek LIPI, t.t).

Adapun tujuan dari penelitian ini adalah menentukan DNA dari mikroba dan memperoleh jenis-jenis mikroba yang koeksis dengan ascidia L. patella.

\section{METODE PENELITIAN}

Sampel ascidia $L$. patella diambil dengan cara menyelam menggunakan alat selam SCUBA, di perairan Malalayang, Sulawesi Utara. Lokasi pengambilan sampel ascidia ditunjukkan pada Gambar 1. Sampel ascidia diambil dengan menggunakan pisau karena ascidia hidup menempel pada karang (Bak et al., 1981 dan Littler, 1995 dalam Donia et al., 2011). Sampel ascidia selanjutnya diletakkan dalam plastik sampel yang berisi air laut. Pengambilan sampel mikroba dilakukan di lapangan dengan cara menekan tubuh ascidia (Lewin and Cheng, t.t). Perlakuan ini dilakukan secara aseptik dengan menggunakan lampu spritus. Erlenmeyer yang berisi sampel mikroba selanjutnya dikocok. Sampel tersebut kemudian dibawa ke Laboratorium Biologi Molekuler dan Farmakologi Kelautan untuk proses menumbuhkan mikroba. Proses menumbuhkan mikroba dalam media berlangsung selama \pm 1 minggu. Sampel mikroba yang telah ditumbuhkan selanjutnya dibawa ke Laboratorium Divisi Bioteknologi, FMIPA, UNSRAT untuk diisolasi DNAnya. Metode yang digunakan untuk isolasi DNA adalah dengan menggunakan Genomic DNA Mini Kit (Geneaid). Bahan yang digunakan 


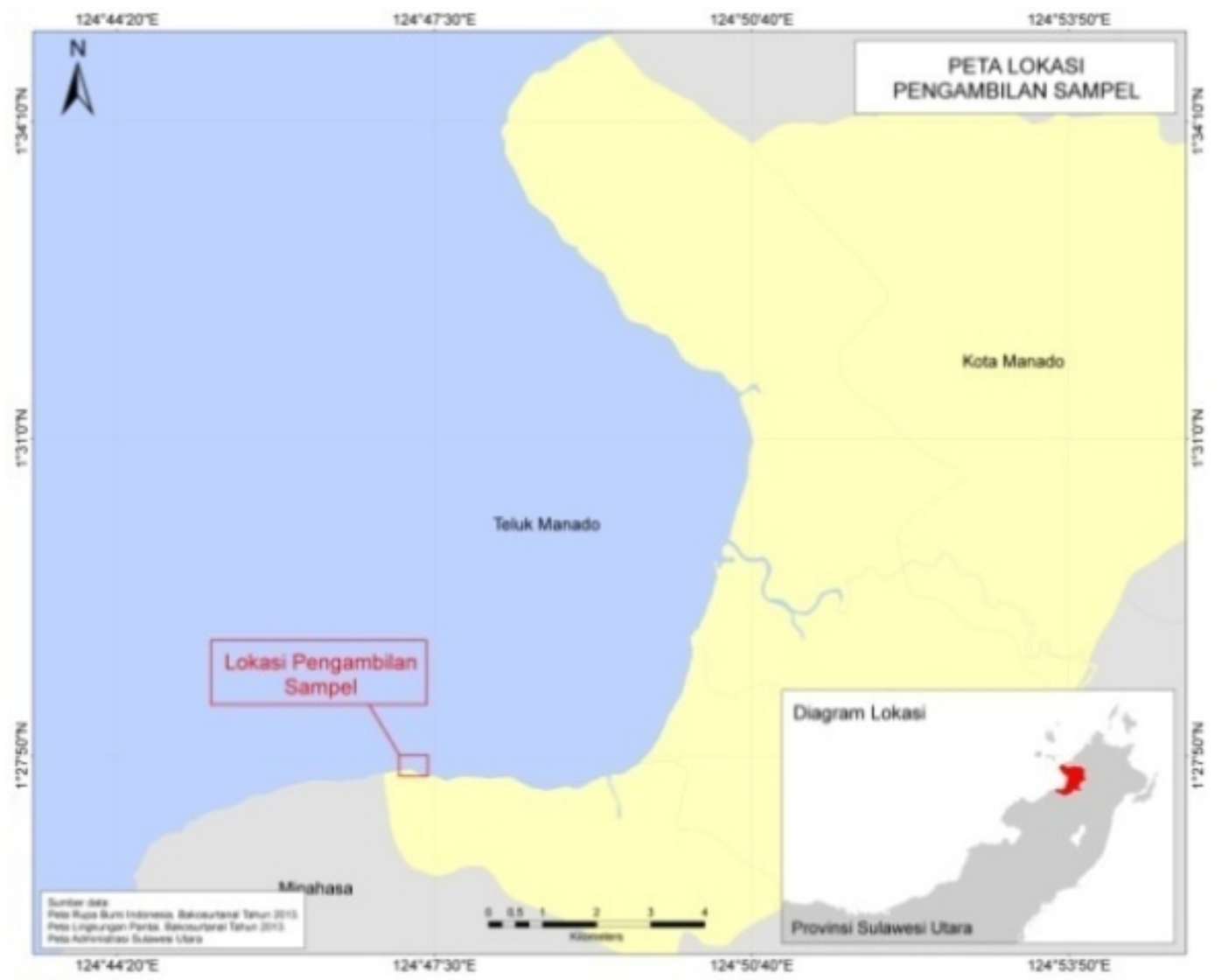

Gambar 1. Lokasi Pengambilan Sampel

dalam isolasi DNA adalah $1000 \mu \mathrm{l}$ sampel mikroba yang diisolasi pada media hirata, serta kit isolasi DNA sampel (Geneaid). Proses berikutnya setelah isolasi DNA adalah proses PCR. Kit PCR yang digunakan dalam penelitian ini adalah 2X Top Taq PCR Master Mix (Qiagen) sedangkan untuk bahan-bahan yang digunakan adalah primer forward 27F (5'AGAGTTTGATCMTGGCTCAG-3'), primer reverse 1492R (5'GGTTACCTTGTTACGACTT-3'), $2 \mu \mathrm{l}$ DNA template (DNA cetakan), $11 \mu \mathrm{l}$ $\mathrm{dd}_{2} \mathrm{O}$, dan $4 \mu \mathrm{l}$ coral load.

Proses PCR dimulai dari tahap denaturasi awal pada suhu $95^{\circ} \mathrm{C}$ selama 3 menit kemudian dilanjutkan 35 siklus, tahap denaturasi pada suhu $95^{\circ} \mathrm{C}$ selama 30 detik, tahap annealing pada suhu $50^{\circ} \mathrm{C}$ selama 30 detik, tahap extension pada suhu $72^{\circ} \mathrm{C}$ selama 1,5 menit dan tahap pemanjangan akhir dengan suhu $70^{\circ} \mathrm{C}$ selama 1 menit.
Hasil PCR dilihat dengan menggunakan elektroforesis gel agarose. Bahan-bahan yang digunakan adalah MaestroSafe Prestained dan Nucleic Acid Gel Stain (MaestroGen, Taiwan) yang disimpan pada suhu $4^{\circ} \mathrm{C}$, $250 \mu \mathrm{l}$ 10X sample loading dye, 10 $\mathrm{mg} / \mathrm{ml}(50 \mu \mathrm{l})$ ethidium bromide, agarose NA sebanyak $5 \mathrm{~g}, 0,1 \mu \mathrm{g} / \mu \mathrm{l}$ ladder DNA marker yang disimpan pada suhu $-20^{\circ} \mathrm{C}$. Hasil PCR tersebut selanjutnya dikirim ke First Base Laboratories, Malaysia untuk disekuensing. Sekuensing yang diperoleh selanjutnya dianalisis menggunakan software Geneious v5.6 (Drummond et al., 2012 dalam Kolondam, 2015) dan BLAST di pangkalan data gen (GenBank) dalam $\mathrm{NCBI}$ (National Center for Biotechnology Information). Data kromatogram hasil sekuensing selanjutnya diedit dan dicari kemiripannya dengan menggunakan 
BLAST. Alur kerja penelitian ini digambarkan dalam suatu bagan proses kerja yang ditampilkan pada Gambar 2.

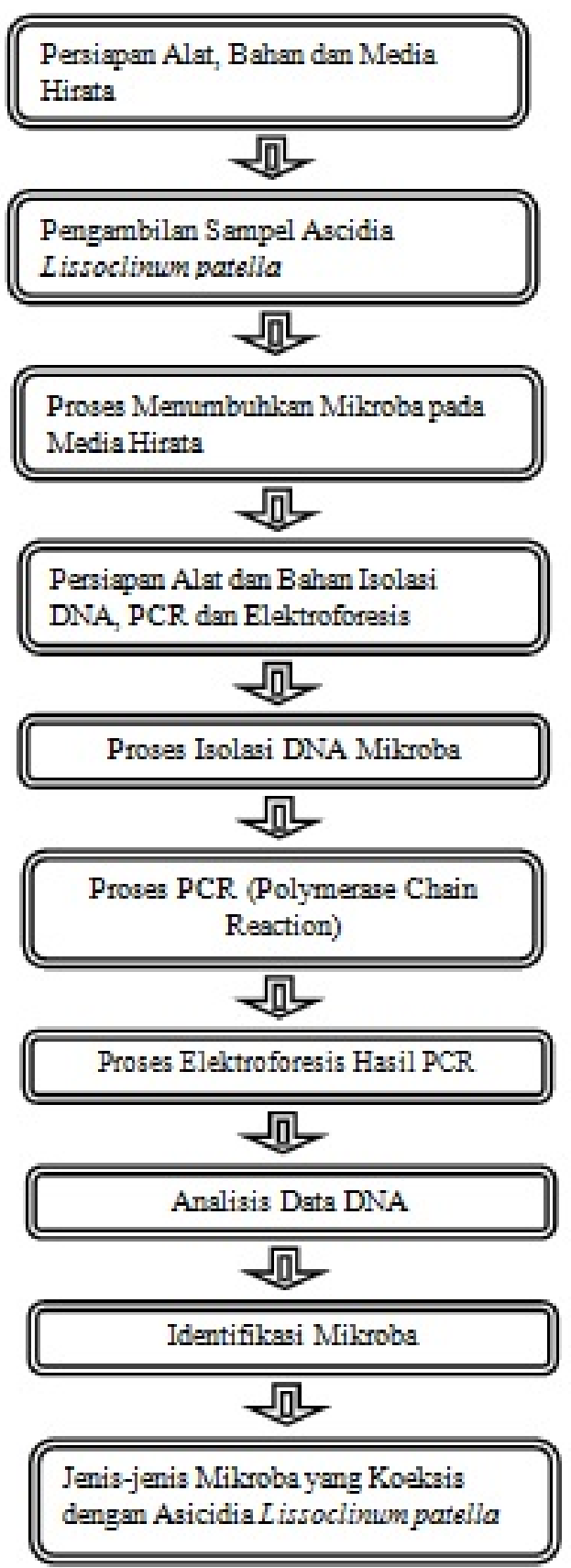

Gambar 2. Alur Kerja Penelitian

\section{HASIL DAN PEMBAHASAN}

\section{Kesuksesan Reaksi PCR Gen 16S rRNA Sampel Mikroba}

Kesuksesan suatu reaksi PCR terlihat melalui band atau pita yang dihasilkan ketika hasil amplifikasi divisualisasikan melalui alat UVtransiluminator (Lamboy, 1994). Gambar 3 memperlihatkan hasil reaksi PCR dari gen 16S rRNA sampel mikroba yang telah divisualisasikan menggunakan UV-transiluminator.

Pita (band) sampel mikroba yang dihasilkan memiliki ciri-ciri berupa pita tunggal dan tebal. Pita tersebut berukuran mendekati marker 1,5 kbp. DNA target untuk amplifikasi melalui PCR kurang lebih berukuran 1,4 kbp sehingga targetnya tercapai. Pita sampel mikroba bahkan terlihat lebih tebal daripada pita marker (konsentrasi DNA ladder $=0,1 \mu \mathrm{g} / \mu \mathrm{l}$ pada volume yang sama. Hal tersebut mengindikasikan bahwa konsentrasi hasil PCR sampel mikroba lebih tinggi sehingga dianggap cukup untuk diproses ke tahap sekuensing.

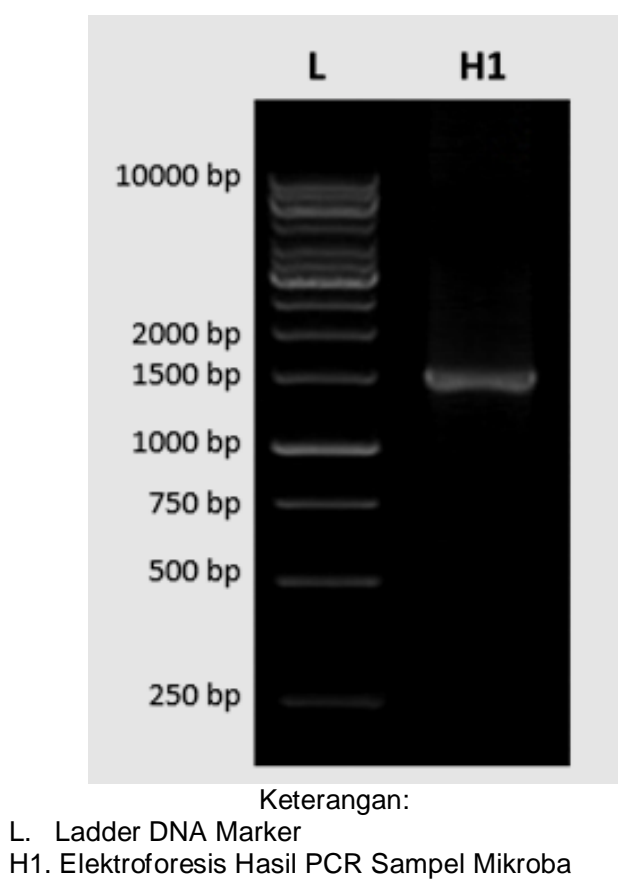

Gambar 3. Elektroforesis gel agarosa $1 \%$ dari sampel mikroba. 



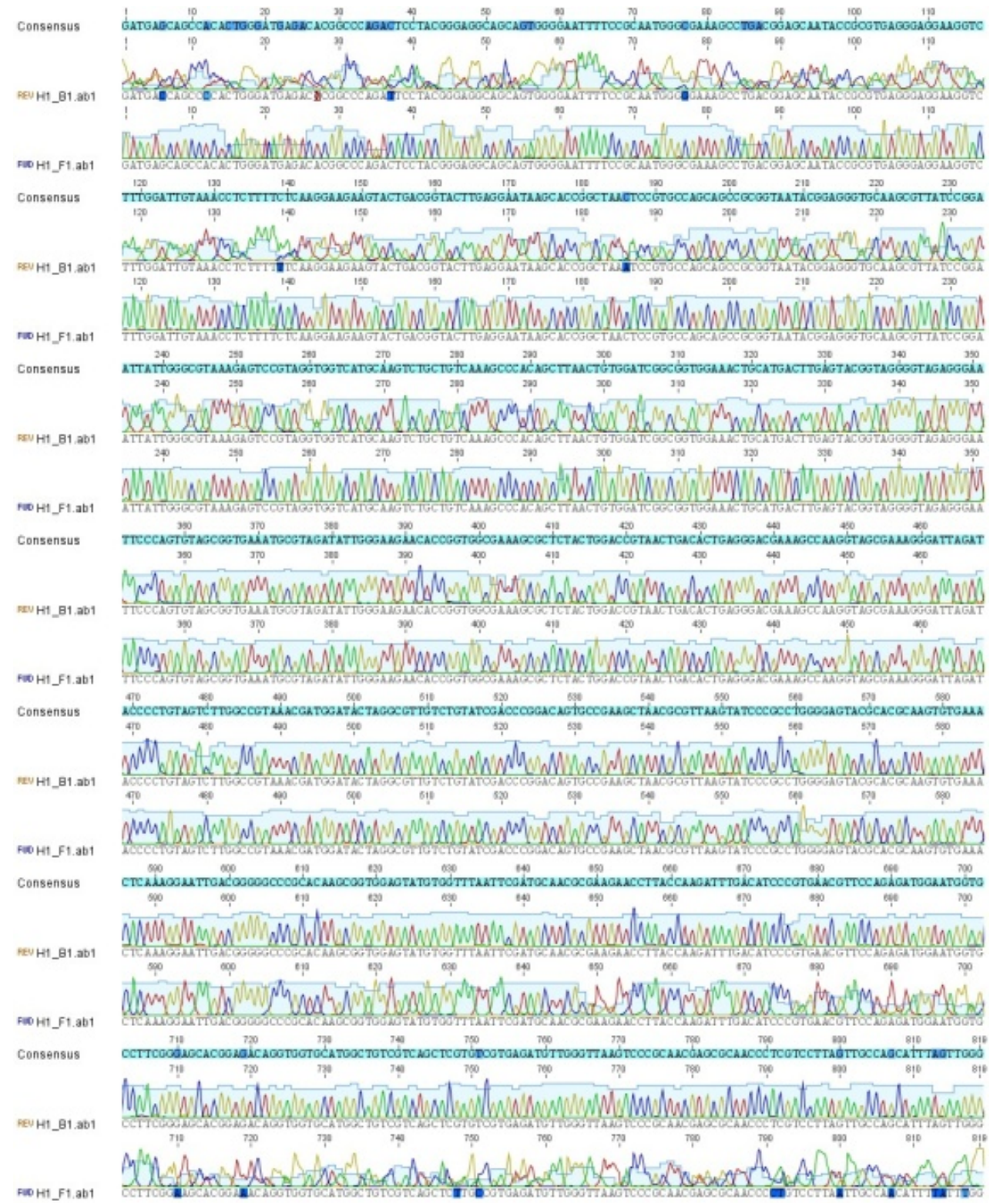

Gambar 4. Penjajaran (alignment) Sekuens Parsial 16S rRNA Sampel Mikroba dari Sekuensing Bi-direksional

\section{Penjajaran Kromatogram Sekuens $16 S$ rRNA Sampel Mikroba}

Sekuens DNA yang diperoleh dalam bentuk kromatogram disunting menggunakan software Geneious v5.6 (Drummond et al., 2012 dalam Kolondam, 2015). Semua data sekuens yang ada (sampel mikroba, primer forward dan reverse) disejajarkan dengan menggunakan program MUSCLE (Multiple Sequence Alignment) yang terintegrasi dalam program Geneious v5.6 (Edgar, 2004 dalam Kolondam, 2015). Penjajaran (alignment) ini merupakan jenis penjajaran bi-direksional (dua arah). Metode bi-direksional ini memiliki keuntungan yaitu dapat saling mencakup sekuens yang tidak bisa dibaca sekuens pasangannya. Keuntungan lainnya yaitu apabila terdapat kesalahan pada pembacaan sekuens DNA maka bisa dikoreksi oleh sekuens komplementernya. 
bisa digunakan yang bersih dan sekuensing memiliki panjang 819 bp. Kromatogram hasil sekuensing fragmen DNA ini juga menunjukkan adanya puncak-puncak dengan 4 warna yang berbeda. Warna-yang berbeda tersebut masing-masing mewakili basa pirimidin dan basa purin tertentu. Basa pirimidin terdiri dari timin yang disimbolkan dengan huruf $T$ dan sitosin yang disimbolkan dengan huruf $\mathrm{C}$ sedangkan basa purin terdiri dari adenin yang disimbolkan dengan huruf $A$ dan guanin yang disimbolkan dengan huruf $\mathrm{G}$ (Dale \& Park, 2010). Keberadaan puncakpuncak yang bervariasi pada kromatogram sampel mikroba menunjukkan adanya bagian yang tidak baik dan bagian yang baik. Bangol dkk. (2014) mengemukakan bahwa hasil sekuensing yang baik ditunjukkan oleh grafik dengan puncak yang tinggi dan saling terpisah satu sama lain. Hasil sekuensing yang tidak baik ditunjukkan dengan puncak yang landai dan tidak saling terpisah satu sama lain atau terdapat puncak ganda pada kromatogram.

$$
\text { Gambar } 4 \text { merupakan }
$$

kromatogram hasil penjajaran (alignment) sekuens parsial 16S rRNA sampel mikroba. Kromatogram tersebut menunjukkan bagian-bagian yang dinamakan "consensus",

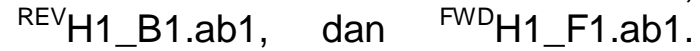
"Consensus" merupakan hasil penjajaran sekuens dua arah gen 16S rRNA dari sampel $\mathrm{H} 1 .{ }^{\mathrm{REV}} \mathrm{H} 1$ B $1 . \mathrm{ab} 1$ adalah sekuens yang disekuensing menggunakan primer reverse sedangkan ${ }^{\mathrm{FWD}} \mathrm{H} 1$ F1.ab1 adalah sekuens yang disekuensing menggunakan primer forward. Basa nukelotida nomor 1-230 pada kromatogram memberikan visualisasi puncak-puncak yang baik dan tidak baik serta terdapat beberapa perbedaan pada basa nukleotidanya. Puncak dengan hasil yang tidak baik ditunjukkan dengan ciri-ciri yaitu, tidak terpisah satu sama lain dan terlihat tumpang tindih. Puncak tersebut berada pada bagian ${ }^{R E V}{ }_{H} 1 \_B 1 . a b 1$. Puncak yang baik ditunjukkan dengan ciri-ciri yaitu, terpisah satu sama lain dan tidak saling tumpang tindih. Puncak tersebut berada pada bagian ${ }^{F W D}$ 1_F1.ab1. Puncak yang tidak baik dan adanya perbedaan basa pada bagian REVH1_B1.ab1 merupakan visualisasi dari pembacaan yang kurang baik namun pembacaan yang kurang baik tersebut telah dicover oleh bagian ${ }^{\text {FWDH1_F1.ab1. }}$

Hal yang sama terjadi pada basa nukleotida nomor 710-819 namun perbedaan pembacaan basa terdapat pada bagian ${ }^{F W D H 1}$ F1.ab1. Puncakpuncak yang ada dikategorikan ke dalam hasil yang tidak baik karena puncak yang ada tersebut tidak saling terpisah satu dengan yang lain dan saling tumpang tindih. Hal berbeda terlihat pada puncak-puncak yang dihasilkan pada bagian ${ }^{\mathrm{REV}} \mathrm{H} 1$ _B1.ab1. Puncak-puncak yang ada menunjukkan hasil yang jelas dengan ciri-ciri yaitu, memiliki puncak yang tinggi dan saling terpisah satu dengan yang lain. Hal ini membuat pembacaan yang kurang baik oleh bagian ${ }^{\text {FWD }} \mathrm{H} 1$ _F1.ab1 dicakup dengan pembacaan yang baik oleh bagian ${ }^{\mathrm{REV}} \mathrm{H} 1$ B 1 .ab1.

Sekuens 16S rRNA sampel mikroba yang diperoleh dari hasil sekuensing ditunjukkan pada Gambar 5. Sekuens tersebut dibuat dalam bentuk format FASTA untuk memudahkan pemindahan text antarplatform penyunting sekuens DNA ke pencari sekuens database GenBank. Sekuens DNA dalam format FASTA dimasukkan sebagai query dalam BLAST (Basic Local Alignment Search Tool pada GenBank NCBI yang bertujuan untuk mengetahui data mikroba apa saja yang memiliki kesamaan tertinggi dengan sampel mikroba. 


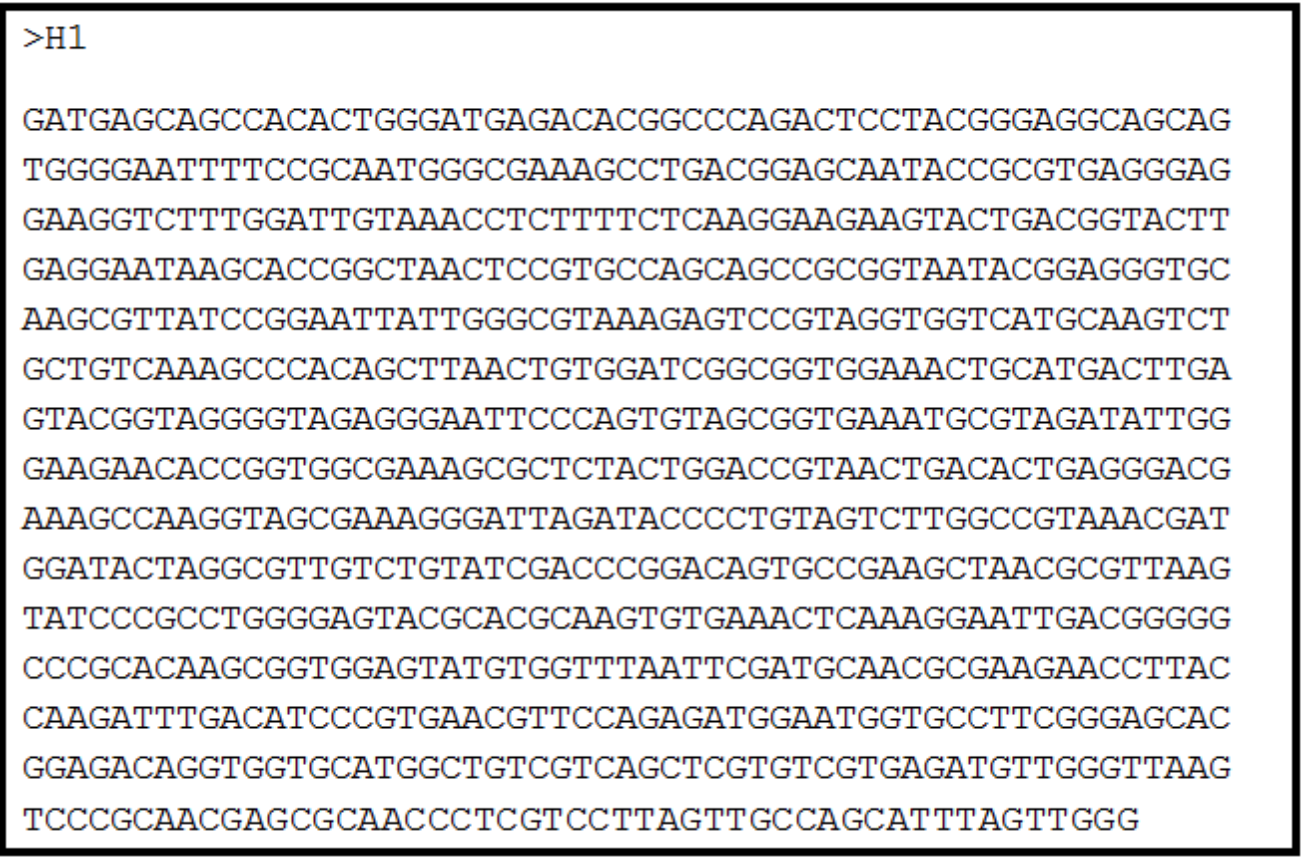

Gambar 5. Sekuens 16S rRNA Sampel Mikroba dalam Format FASTA

Ostell et al. (2001) mengemukakan bahwa format FASTA memuat sebuah baris definisi dan karakter dari sekuens yang dapat digunakan sebagai input bagi sebuah variasi dari programprogram analisis. Hal inilah yang dimanfaatkan untuk memperoleh informasi jenis mikroba yang memiliki tingkat kesamaan tertinggi dengan sampel mikroba melalui input format FASTA tersebut sebagai query dalam BLAST (Basic Local Alignment Search Tool) pada GenBank NCBI. Selain itu, sekuens dalam format FASTA tersebut juga akan memudahkan pemindahan text antar-platform penyunting sekuens DNA ke pencari sekuens database GenBank pada NCBI.

\section{Identifikasi Mikroba Menggunakan Sekuens Gen 16S rRNA}

Pencarian yang dilakukan menggunakan BLAST dalam GenBank pada NCBI (National Center for Biotechnology Information) menghasilkan data seperti yang ditunjukkan pada Gambar 6.
Pada gambar 6 dapat dilihat bahwa nilai query cover dari setiap mikroba pada GenBank yang memiliki tingkat kesamaan tertinggi dengan sampel mikroba menunjukkan angka $100 \%$. $\mathrm{Hal}$ ini menunjukkan bahwa, query dari mikroba-mikroba dalam GenBank mencakup seluruh bagian query dari sampel mikroba. Berdasarkan hasil penelusuran tersebut, mikroba-mikroba pada GenBank yang memiliki tingkat kemiripan tertinggi dengan sekuens sampel mikroba dari media hirata ditunjukkan pada Tabel 1.

Pada Tabel 1 tersebut terdapat kode akses dari setiap mikroba. Kode akses tersebut digunakan untuk memperoleh data dari mikroba pada GenBank dalam NCBI. Selain itu, kode akses tersebut juga digunakan sebagai input dalam NCBI untuk penjajaran (alignment) sekuens mikroba dengan sekuens sampel mikroba. Hasil penjajaran (alignment) yang diperoleh memperlihatkan kemiripan dari sekuens sampel mikroba dan mikroba dalam GenBank. Penjajaran (alignment) tersebut ditunjukkan oleh Gambar 7 yang merupakan penjajaran sekuens 


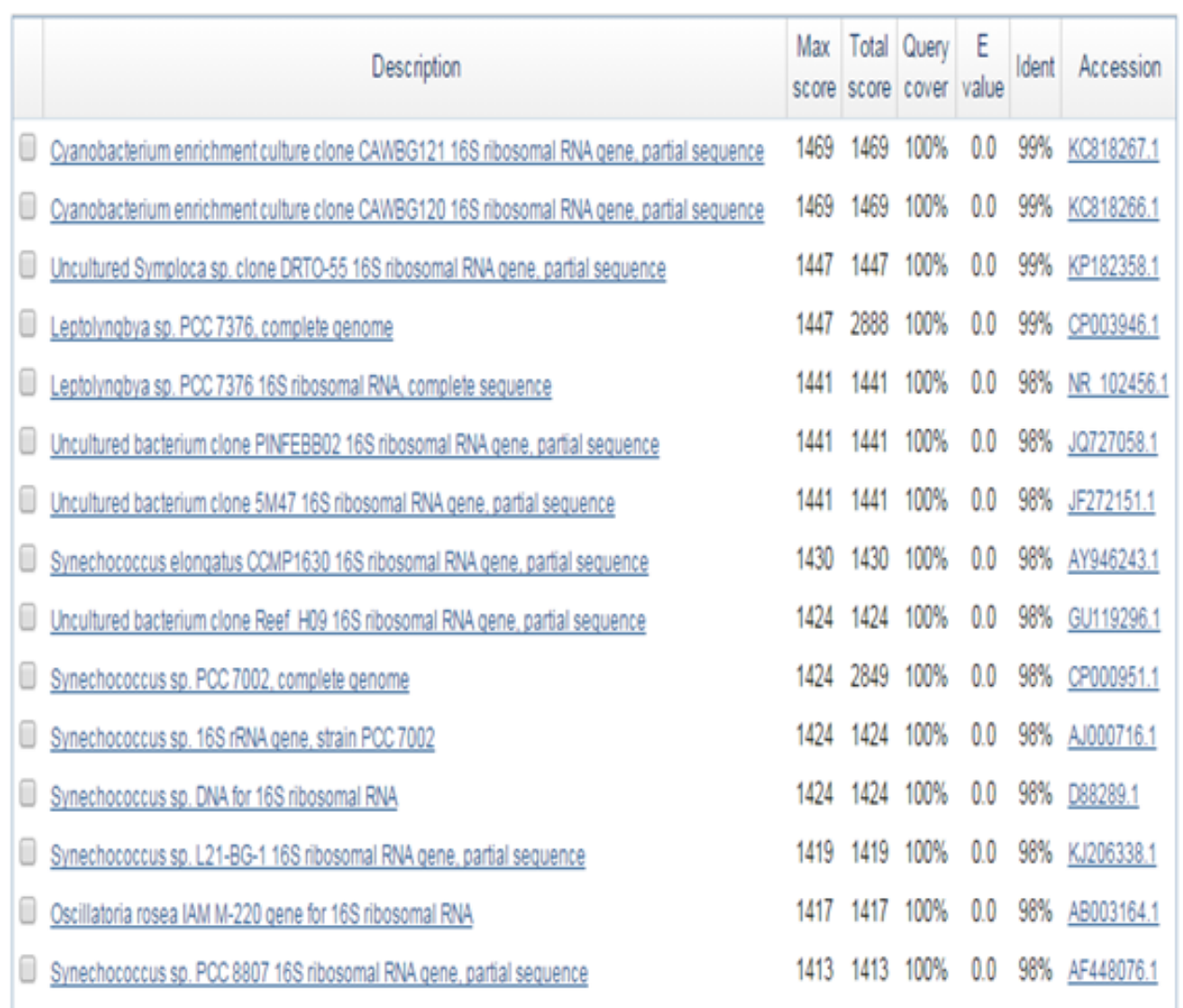

Gambar 6. Hasil Penelusuran BLAST (Basic Local Alignment Search Tool) di NCBI (diakses tanggal 18 Juni 2015).

sampel mikroba dengan sekuens mikroba yang memiliki kemiripan tertinggi yaitu cyanobacterium encrichment culture clone CAWBG121.

Tabel 1. Mikroba yang Memiliki Tingkat Kemiripan Tertinggi dengan Sampel Mikroba

\begin{tabular}{|c|c|c|c|}
\hline No & Kode Akses & Jenis Mikroba & Kemiripan \\
\hline 1. & KC818267 & $\begin{array}{l}\text { Cyanobacterium enrichment culture } \\
\text { clone CAWBG121 }\end{array}$ & $99 \%$ \\
\hline 2. & KC818266 & $\begin{array}{l}\text { Cyanobacterium enrichment culture } \\
\text { clone CAWBG120 }\end{array}$ & $99 \%$ \\
\hline 3. & KP182358 & $\begin{array}{l}\text { Uncultured Symploca } s p \text {. clone } \\
\text { DRTO- } 55\end{array}$ & $99 \%$ \\
\hline 4. & CP003946 & $\begin{array}{l}\text { Leptolyngbya sp. PCC } 7376 \text { complete } \\
\text { genome }\end{array}$ & $99 \%$ \\
\hline 5. & NR102456 & Leptolyngbya sp. PCC7376 & $98 \%$ \\
\hline 6. & JQ727058 & $\begin{array}{l}\text { Uncultured bacterium clone } \\
\text { PINFEBB02 }\end{array}$ & $98 \%$ \\
\hline 7. & JF272151 & Uncultured bacterium clone $5 \mathrm{M} 47$ & $98 \%$ \\
\hline 8. & AY946243 & $\begin{array}{l}\text { Synechococcus elongatus } \\
\text { CCMP1630 }\end{array}$ & $98 \%$ \\
\hline 9. & GU119296 & $\begin{array}{l}\text { Uncultured bacterium clone Reef } \\
\text { H09 }\end{array}$ & $98 \%$ \\
\hline 10. & CP000951 & $\begin{array}{l}\text { Synechococcus sp. PCC } 7002, \\
\text { complete genome }\end{array}$ & $98 \%$ \\
\hline 11. & AJ000716 & $\begin{array}{c}\text { Synechococcus sp. 16S rRNA gene, } \\
\text { strain PCC } 7002\end{array}$ & $98 \%$ \\
\hline 12. & D88289 & $\begin{array}{c}\text { Synechococcus sp. DNA for } 16 \mathrm{~S} \\
\text { nibosomal RNA }\end{array}$ & $98 \%$ \\
\hline 13. & KJ206338 & Synechococcus sp. L21-BG-1 & $98 \%$ \\
\hline 14. & $\mathrm{AB} 003164$ & Oscillatoria rosea IAM M-220 & $98 \%$ \\
\hline 15. & AF448076 & Synechococcus sp. PCC 8807 & $98 \%$ \\
\hline
\end{tabular}

Jumlah basa nukleotida sampel mikroba yang sama atau mirip dengan basa nukleotida cyanobacterium encrichment culture clone CAWBG121 adalah 812 dari 820 basa. Dengan kata lain, terdapat 8 perbedaan pada hasil sekuens sampel mikroba dan cyanobacterium encrichment culture clone CAWBG121. Perbedaan tersebut ditandai dengan tidak adanya garis tegak lurus sebagai tanda kesamaan basa pada kedua sekuens. Perbedaanperbedaan tersebut terdapat pada basa nukleotida nomor 235, 368, 510, 898, 912, 927, 1022 dan 1027 untuk sekuens cyanobacterium enrichment culture clone CAWBG121. Perbedaan pada sampel mikroba ditemukan pada basa nukleotida nomor 21, 133, 295, $683,697,712,807$ dan 812. Selain itu, basa nukleotida nomor 21 pada sekuens sampel mikroba tidak terlihat adanya huruf yang menunjukkan kode basa. 


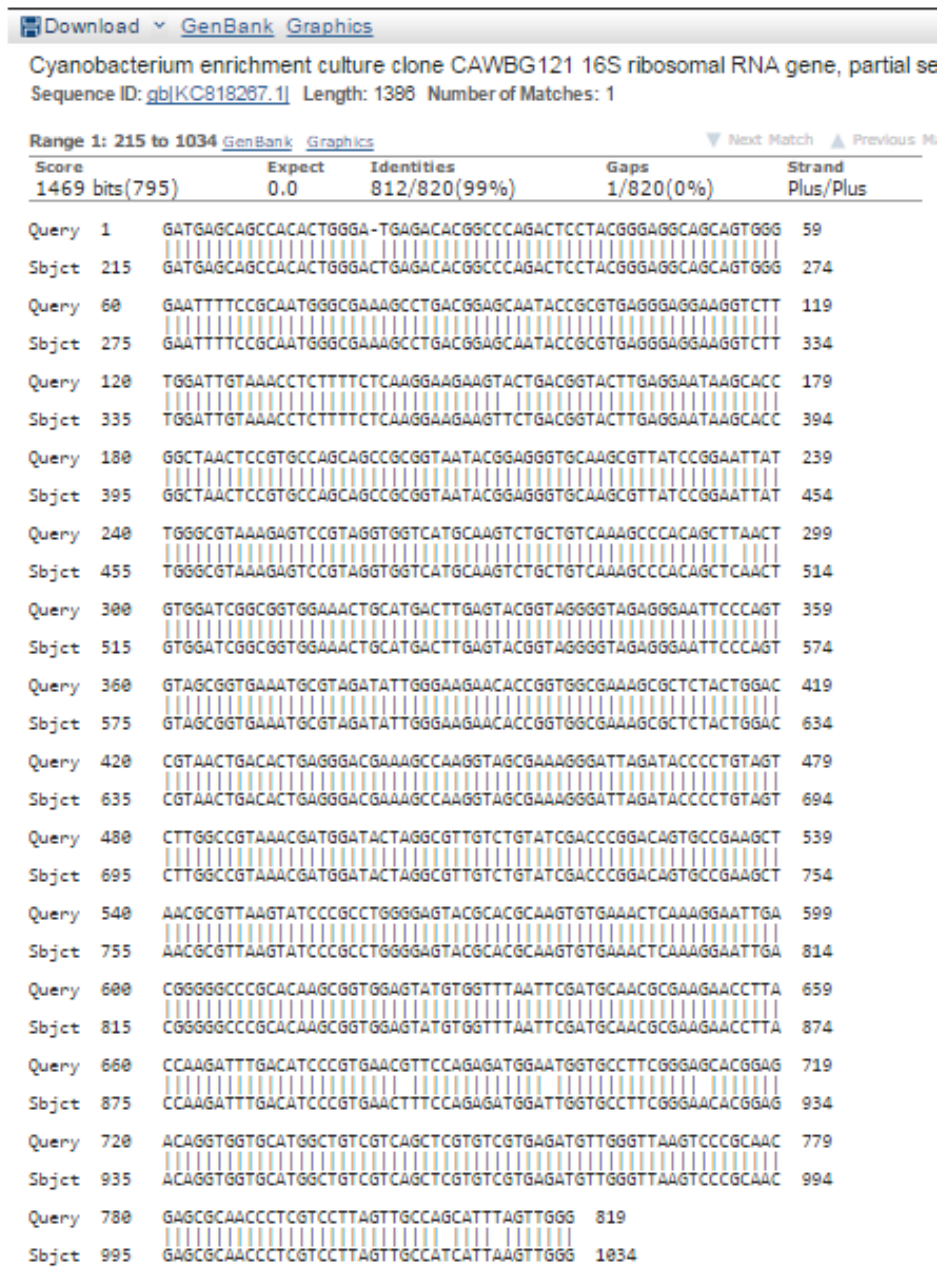

Gambar 7. Penjajaran (Alignment) Sampel Mikroba dengan Cyanobacterium (Nomor Aksesi: KC818267)

Tingkat kemiripan $99 \%$ yang diperoleh merupakan nilai total dari jumlah basa mikroba pada GenBank dibagi dengan total jumlah basa yang sama dengan sampel mikroba, dalam hal ini 820 basa dibagi 812 basa.

\section{Identifikasi Mikroba Koeksis dengan Ascidia L. patella}

Berdasarkan data DNA yang ada, sebagian besar mikroba yang mirip dengan sampel mikroba dari ascidia $L$. patella yang dikultur pada media hirata didominasi oleh Sianobakteri. Hal ini sesuai dengan pendapat Kott, (1982); Kott et al., (1984) dalam Hirose et al., (2012) yang mengemukakan bahwa beberapa jenis ascidia memiliki hubungan dengan Sianobakteri.
Sianobakteri adalah grup prokariotik autotrof purba yang berukuran besar, dan dapat melakukan fotosintesis. Sianobakteri mengandung substansi intraseluler seperti glikogen, cyanophycin, fikobiliprotein dan polifosfat (Rai et al., 2000). Sianobakteri juga memiliki sebuah membran berisi nukleus dan membran yang berisi organel-organel (Fogg et al., 1973 dalam Watkinson, 1999). Sianobakteri dapat hidup apabila terdapat unsur-unsur yang mendukung kehidupannya seperti nitrogen, fosfor, besi, dan molibdenum (Watkinson, 1999).

Sampel mikroba memiliki tingkat kemiripan tertinggi dengan Sianobakteri jenis cyanobacterium enrichment culture clone CAWBG121 yang 
dikoleksi dari daerah aliran sungai Utakura yang dinamakan aliran Waihau, New Zealand. Daerah pelabuhan Hokinga di New Zealand memperoleh masukan air tawar yang cukup signifikan dari danau Omapere melalui sungai Utakura (Wall et al., 2013). Kondisi perairan Malalayang yang merupakan lokasi pengambilan sampel ascidia $L$. patella juga mengalami hal yang sama yaitu mendapat masukan air tawar dari daerah aliran sungai yang jaraknya \pm $100 \mathrm{~m}$ dari lokasi tersebut seperti yang ditunjukkan pada Gambar 1.

Berdasarkan hasil identifikasi data DNA mikroba pada GenBank yang mirip dengan sampel mikroba isolat dari ascidia $L$. patella, diperkirakan bahwa keberadaan mikroba pada ascidia $L$. patella di perairan Malalayang berasal dari mikroba dalam air tawar yang masuk ke perairan melalui aliran sungai di dekat lokasi pengambilan ascidia. Mikroba tersebut masuk ke dalam ascidia melalui cara makan filter feeder. Filter feeder adalah proses dimana ascidia menangkap partikel sedimen yang berasal dari lingkungan luar. Sedimen tersebut perlahan jatuh ke dalam oral siphons bersamaan dengan air yang rata-rata masuk berkisar antara 2-3 liter sampai18,5 liter per jam (Daniel \& Therriault, 2007). Proses tersebut dinamakan horizontal transmission.

\section{KESIMPULAN}

Data DNA mikroba dalam GenBank yang mirip dengan sampel isolat mikroba dari ascidia L. patella menunjukkan letak kemiripan dan persentase tingkat kemiripan. Tingkat kemiripan tertinggi antara sekuens mikroba dalam GenBank dan sampel isolat mikroba berada pada nilai $99 \%$. Identifikasi menggunakan sekuens gen 16S rRNA menunjukkan bahwa mikroba yang koeksis dengan ascidia L. patella di perairan Malalayang berasal dari golongan
Sianobakteri jenis cyanobacterium enrichment culture clone CAWBG121.

\section{DAFTAR PUSTAKA}

Bangol, I., L. I. Momuat., dan M. Kumaunang. 2014. Barcode DNA Tumbuhan Pangi (Pangium edule). Berdasarkan Gen matK. Jurnal MIPA UNSRAT ONLINE, 3 (2): 113-119.

Behrendt, L., A. W. D. Larkum., E. Trampe., A. Norman., S. J. Sorensen, and M. Kuhl. 2012. Microbial Diversity of Biofilm Communities in Microniches Associated with The Didemnid Ascidian Lissoclinum patella. The ISME Journal, 6: 1222-1237.

Bioteknologi LIPI. (t.t). Diagnostik Molekuler: Potensi dalam Jasa dan Penelitian Kesehatan. Diunggah 5 Maret 2015, dari http://www.biotek.lipi.go.id/.

Daniel, K. S., and T. W. Therriault. 2007. Biological Synopsis of The Invasive Tunicate Didemnum sp. Canadian Manuscript Report of Fisheries and Aquatic Sciences. 2788 (6): 53.

Dale, J. W., and S. F. Park. 2010. Molecular Genetics of Bacteria. United Kingdom: John Wiley \& Sons, Ltd., Publication. p 388.

Donia, M.S., B.J. Hathaway., S. Sudek., M.G. Haygood. M.J. Rosovitz., J. Ravel. and E.W. Schimdt. 2006. Natural Combinatorial Peptide Libraries In Cyanobacterial Symbionts of Marine Ascidians. Nature Publishing Group, 2 (12): 729-735.

Donia, M.S., W.F. Fricke., F. Partensky., J. Cox., S.I. Elshahawi., J.R. White., A.M. Phillippy., M.C. Schatz., J. Piel., 
M.G. Haygood., J. Ravel., dan E.W. Schmidt. 2011. Complex Microbiome Underlying Secondary and Primary Metabolism In The TunicateProchloron Symbiosis. PNAS PLUS Microbiology, 108 (51): 1423-1432.

Hirose, E. and T. Maruyama. 2004. What Are The Benefits In The Ascidian-Prochloron Symbiosis. Endocytobiosis Cell Res, 15: 5162.

Hirose, E., X. Turon., S. LopezLegentil., P.M. Erwin., and M. Hirose. 2012. First Records Of Didemnid Ascidians Harbouring Prochloron From Caribbean Panama: Genetic Relationships Between Caribbean And Pacific Photosymbionts And Host Ascidians. Taylor and Francis Group, 10 (4): 435-445.

Kolondam, B.J. 2015. Applying matK Gene for Identification of Liliopsida Plant Species From North Sulawesi Through Bold Systems. International Journal of Applied Biology and Pharmaceutical Technology, 6 (2): 242-245.

Lamboy, W.F. 1994. Computing Genetic Similarity Coefficients from RAPD Data: The Effects of PCR Artifacts. Cold Spring Harbor Laboratory Press, 4: 31-37.

Lewin, R.A and L. Cheng. 1989. Prochloron: A Microbial Enigma. Chapman and Hall. New York. $\mathrm{p}$ 115.

Lewin, R.A dan L. Cheng. (t.t). Collection and Handling of Prochloron and Its Ascidian Hosts. In: R. A. Lewin \& L. Cheng (Eds.). Prochloron A Microbial Enigma. New York: Chapman \& Hall, Inc. 9 pp.
Nybakken, J.W. 1992. Biologi Laut: Suatu Pendekatan Ekologis. Eidman, M., Koesoebiono, D.G. Begen, M. Hutomo., dan S. Sukardjo [Penerjemah]. Terjemahan dari: Marine Biology: An Ecological Approach. PT.Gramedia. Jakarta. 459 hal.

Ostell, J. M., S. J. Wheelan., and J. A. Kans. 2001. The NCBI Data Model. In: A. D. Baxevanis \& B. F. F. Ouellette (Eds.). Bioinformatics: A Practical Guide to the Analysis of Genes and Proteins, Second Edition. John Wiley \& Sons, Inc. 19-43 pp.

Rai, A. N., E. Soderback., and B. Bergman. 2000. Cyanobacterium-Plant Symbioses. Review New Phytol, 147: 449-481.

Schmidt, W.E., J.T. Nelson., D.A. Rasko., S. Sudek., J.A. Elson., M.G. Haygood. and J. Ravel. 2005. Patellamide $A$ and $C$ Biosynthesis By A Microcin-like Pathway in Prochloron didemni, The Cyanobacterial Symbiont of Lissoclinum patella. The National Academy of Sciences of The USA, 102 (20): 7315-7320.

Watkinson, A. 1999. Ecophysiology of Marine Cyanobacterial Blooms. Literature Review Submitted to The Department of Botany, University of Queensland. Australia. p 48. 